\title{
Individualism of Hester Prynne in the Seventeenth Century Puritan Society: The Scarlet Letter
}

\author{
Ms. Mursalin Jahan \\ Assistant Professor and Research Scholar, Integral University, Lucknow, Uttar Pradesh, India \\ Prof. Syed Zaheer Hasan Abidi
}

Senior Professor, Head in the Department of English/Languages \& Dean

Faculty of Humanities \& Social Sciences, Integral University, Lucknow,India.

\begin{abstract}
In Nathaniel Hawthorne's The Scarlet Letter Hester Prynne, the female protagonist living amidst the strict puritans is a typical individualist. After being charged with adultery, she is shunned, mocked and viewed as a living allegory of sin. Her punishment is to wear the scarlet letter 'A', a symbol of sin, on her bosom throughout her life. She does not dramatically and apologetically beg for forgiveness; instead, she endures her punishment and ultimately, with her "natural dignity and force of character", she turns a symbol of sin into a symbol of strength. She is an emersonian self-reliant woman as she trusts her deepest instincts and values her own inner truth in making her judgments. The present paper focuses on how she crushes the puritan's codes of conduct and moves forward in her life based on her own principles of right and wrong.
\end{abstract}

Keywords: Adultery, allegory of sin, codes of conduct, Emersonian self-reliant, individuality, puritans

The Scarlet Letter, published in 1850, is Nathaniel Hawthorne's the most renowned and wellreceived romance. It is set in the seventeenth century puritan society. During puritan's times, women were submissive and obedient to the wishes and desires of the males. They were not permitted to express their views, opinions or emotions in public. Puritans believed that knowledge, intelligence and the freedom of expression were only meant for males. They were of the opinion that women were more tempted to evils and in turn more likely to go to hell than men . In brief, female population was "oppressed, damned, condemned" and are dominated by males in all the aspects of their lives. In The Scarlet Letter Hawthorne associates Puritanism with "superstition, excessive moralism, intolerance, and patriarchal operation" (Person 17). Hester Prynne, the female protagonist living amidst the strict puritans is different from the women of her time. She is a typical individualist. After being charged with adultery, she is shunned, mocked and viewed as a "living allegory of sin". Her punishment is to wear the flaming letter ' $A$ ' on her bosom throughout her life. Towards the end of the novel, she convinces her fellow sinner to abandon the narrow- minded community and settle with her sin-born daughter Pearl elsewhere in a free atmosphere to assert her individuality. She is an emersonian selfreliant as she trusts her deepest instincts and values her own inner truth in making her judgments.

The word individualism was first used in 1820 in a pejorative sense by Joseph de Maistre, a French thinker, but it was applied to America by Tocqueville to describe the new emerging ideology of the people of America. Individualism as defined by Rutherford in his article "A Bibliographic Essay on Individualism" is "the position that gives priority to individual as both source and beneficiary of social action and as the ultimate measure of what is good" (116). Individualist encourages the exercise of one's own goals and desires and therefore gives importance to freedom and self-reliance and propagates that the interest of the individual should be given priority over the state or a social group. Ralph Waldo Emerson who led Transcendental Movement propagated the notion of self-reliance which encourages the principle of trusting one's own deepest thoughts and moral instincts. The heartwarming appeal of his essay "Self-reliance" talks of unthinking non-conformity to society. He put forth his doctrine: "Imitation is suicide; that he must take himself for better, for worse, as his portion ....Whose would be a man must be a non-conformist.... Nothing is at last sacred but the integrity of your own mind" (Emerson 2-4). Hester is self-reliant as she is inclined to listen to her own conscience and trusts her own ability to make her judgments.

Hester Prynne, the anti-puritan rejects all the codes of conduct set up by the puritans. In the beginning of the novel, she repels the town beadles "by an action marked with natural dignity and force of 
character, and stepped into the open air as if by her own free will" (Hawthorne 39). The way she comes out of the prison is enough to penetrate deep into her intention of non-conforming to the puritan laws and their ideologies. Lehtie Chalise Thomson observes her intention and writes, "Hester, the anti-Puritan, arrives in splendor and grandeur, shocking the spectators with her self-assurance and boldness. Such an introduction to her hints that she has no intention of obeying the Puritan magistrates" (72).

The puritans want to punish Hester so horribly to set an example in front of others so that they dare not commit a similar sin. She is led to the scaffold as an "emblem of sin", fully revealed to the crowd where she is to be humiliated publicly by criticism and shaming words. Though the puritans intend to break Hester down with public humiliation, but ironically the platform serves as a mean to strengthen her inward sphere. The puritan community wants to obliterate her individuality by compelling her to wear a badge of shame on her bosom but the badge has been transformed into the lamp, illuminating the darkness created by the dark principles set by the puritans. The scarlet letter, 'A' fastened on her dress has a magical effect, taking her out of the crowd surrounding her in a sphere by herself. She is not rebellious against the puritan's treatment but suffers the humiliation silently. She on one hand obeys the puritan laws but on the other hand crushes them intelligently. She wears the badge of shame as a punishment but paradoxically she decorates that letter with "elaborate embroidery and fantastic flourishes of gold thread" which looks as if she is wearing a golden necklace with its true feelings. Due to its orateness, the letter is far away from serving its real purpose. Matide Mansilla writes in her research paper titled "An Insight into the Inward Sphere in Hawthorne's The Scarlet Letter" that, "It is through such provocative exhibition of individuality that Hester makes it known that while enduring her punishment, she can simultaneously leads her life as she chooses"(221).

When Hester is asked to reveal the name of her fellow sinner, she remains silent. She uses silence as the powerful weapon to show her resistance against puritans. Leland S. Person in his article "Hester's Revenge: The Power of Silence in The Scarlet Letter" studied her silence in the context of feminine criticism that, "It is both fitting and ironic that Hester's revenge should take a "silent" form: fitting because of Dimmesdale's own silence; ironic because, as feminist critics have argued, women are customarily "silenced" in male-authored texts in order to be rendered powerless" (Person 471). Silence, a submissive trait of a woman becomes a powerful weapon to assert her individualism against puritans. Though, she is free to remove the scarlet letter if she repents and reveals the name of her lover, but she refuses, because she does not want puritans to exercise their power over her. Puritans attempt to curb her independent spirit but they are unable to force her to comply. Suzan Last writes in her article "Hawthorne's Feminine Voices: Reading The Scarlet Letter as a woman" that, "Her refusal to name the father of her child confounds the leaders of the community. This refusal to be bound to a "father," even if beyond the laws of marriage, gives Hester a greater individuality"( 360).Thompson also argues in his article "Moral Wilderness in The Scarlet Letter" by saying that, "Starting with her refusal to name her lover, Hester's actions demonstrate an independence from rules and regulations. She chooses her own course, dismisses the cultural framework surrounding her, and leans heavily upon creating a personal spirituality exempt from external forces"( 76). She has separated herself from all the principles set up by the puritans. These initial steps taken by Hester shows that she is taking her first step towards a sort of Emerson's philosophy of self- reliance.

The puritan law is like an "iron fisted giant" who has the vigor to either support or annihilate her. Her punishment is to wear the scarlet letter, the symbol of shame throughout her life. The condition of a punishment does not compel her to live in Boston, remote and obscure puritan settlement. She is free to return to her birth place or to any other European land and lead a life without shame with a new exterior but, to the surprise of all she chooses to settle in Boston at the outskirts of the town away from the other inhabitants in a small thatched cottage. It is argued that she can hide her identity as an adulterer with a completely another state of being by settling herself away from a place where she is identified as an adulterer. But, the cruel taunts and alienation which she faces while standing on the scaffold for three hours infuses her determination to face the puritans boldly rather than leaving Boston. She gains new energy and vigor to rebel against the puritans. Her sin and ignominy has given birth to a new Hester who is ready to face the consequences of her past. The roots of her "sin and ignominy" are deep rooted into the soil of Boston. She feels that if here is the scene of her sin, then it should also be the scene of her punishment. Another reason is that she cannot bear to be departed from Arthur Dimmesdale, her fellow sinner with whom she dreams herself "connected in a union" (Hawthorne 60). If she had fled, she would be acknowledging puritan's power over the course of her 
individuality. Also, she does not leave Boston because she wants to redeem of her sin in her own way by staying among the puritans without the guidance of the magistrates. She does not want to hide the stigma of shame by her new exterior but she wants to eradicate it by her actions to lead a respectable life in front of those who hate her. She wants to emerge as a new individual within the puritans. She believes that "perchance, the tourcher of her daily shame would at length purge her soul, and work out another purity than that which she had lost: more saint-like, because the result of martyrdom".( Hawthorne 61).

By residing at the outskirt of the town, she carries the responsibility of a single parent with "grace and fortitude". She does not give Pearl to the magistrates. Though she suffers all the torments silently without open rebellion against the puritans, but she is courageous enough to rebel openly when the time demands. When she is asked to hand over Pearl to magistrates, she exhibits her courage and "caught hold of Pearl, and drew her forcibly into her arms, confronting the old Puritan magistrate with almost a fierce expression"( Hawthorne 84). She feels that she posses an indefeasible right to her daughter and is ready to defend her right to her death. She stands alone against the puritans for the sake of her little Pearl and raises her voice almost to a shriek and says, "God gave her into my keeping!...I will not give her up!" (Hawthorne 84). She refuses even to name the father of Pearl and undertakes the responsibility of upbringing her daughter alone which gives Hester a great individuality. She is neither ready to disclose the name of the father of Pearl nor wants to take off the scarlet letter ' $A$ ' from her bosom. Her strong determination is even admired by the puritan magistrates as said by Jumat Barus in her article entitled "Nathanial Hawthorns The Scarlet Letter as a Tragic Love Story" says:

They admire Hester Prynne for the strong determination that she shows in refusing to disclose the name of her partner in her crime. Neither the terrible threats of the reverend Mr. Wilson nor the eloquent appeal of the reverend Mr. Dimmesdale has any effect upon her. By disclosing the name, she can perhaps have the scarlet letter taken off her breast and she can also give her child a father. But she tells the priest that the scarlet letter is too deeply branded on her breast to be taken off and that her child must seek a heavenly father. Not only does she not disclose the name of her lover, but she declares that she would like to endure his agony in addition to her own. Hester Prynne,,s words compel Dimmesdale to acknowledge her strength and her generosity. (205).

She is not ready to act against her impulses just to set herself free from harsh puritans. She does not conform or surrender herself to the demands of the puritans instead emerges out to be an individual who asserts her individualism by stepping forward on the path chosen by herself against the desires of the puritans. She does not refrain herself from being the member of the society but is separated from the society's perception of what is right and wrong. She judges what is right and wrong based on her own principles and acts accordingly.

She is a sinner in the eyes of the puritan government but the sin which she committed is a "sin of passion, not of principles, nor even purpose" (Hawthorne 143). But how does Hester takes her sin as? Is she ashamed or proud of her sin? There are so many instances in novel which clearly reflects that she is proud rather than ashamed of her sin. The orateness of the scarlet letter, the symbol of shame seems to declare her feelings in context with the sin of adultery with Dimmesdale. She does not wear it as a sign of shame but as a token of love which makes her feel individually different from the rest of the women of puritan society. Sylvia Eekman in her research paper "Women in The Scarlet Letter" interprets the golden embroidery around the scarlet letter as a tribute to that love, which does not go entirely unnoticed by the puritan's female (59).

She hath good skill at her needle, that"s certain," remarked one of the female spectators; "but did ever a woman, before this brazen hussy, contrive such a way of showing it! Why, gossips, what is it but to laugh in the faces of our godly magistrates, and make a pride out of what they, worthy gentlemen, meant for punishment? (Hawthorne 40).

The puritan women do not dare to take such a bold step because of its strict imposition upon each member demanding moral responsibility and discipline. She does not wear the scarlet letter for redemption but as a reminder of her affair with Dimmesdale. Nina Baym adds:

It is hoped that the external letter will work its way down into Hester's heart and cause repentance, but nobody really cares and this indifference is Hester's freedom. In fact, the effect of 
the letter so far as Hester's character is concerned is the opposite of what was intended: turning her into a public symbol, it conceals her individuality and thus protects it. (69).

He love for Dimmesdale with whom she has sinned; her love for the scarlet letter, the symbol of sin ; her love for Pearl, the product of her sin clarifies that she is not guilty of her act of adultery and does not take it as a sin. Further, she does not consider her act to be evil because she is not disloyal to her estranged husband, whom she has never loved or to the traditional morality in which she has never believed. She herself has never admitted to any sin other than deceiving Dimmesdale and has never acted selfishly and has worn her scarlet letter triumphantly, rather than penitently. She preserves Dimmesdale's secret because she wants him to assert his own free will and confesses his sin.

In puritan society, women are regarded as dependent upon men, which results into the tragic life of women. Hester revolts against this social order of puritan society tenaciously and gains self- reliance in economy by serving her daughter and herself by her uncommon talent in the needlework. "In the Puritan society, who would succeed and who would fail are not determined by himself or herself, but by God. Man is divided into two groups. And the bad people cannot save or relieve themselves until they appeals to God's help"(qtd.in "A Representative of the New Female Image" 896). This holy idea which is not subjected to change is changed by Hester by her indefeasible courage and strength. "She possessed an art that sufficed, even in a land that afforded comparatively little scope for its exercise, to supply food for her little infant and herself". ( Hawthorne 61). The scarlet letter, she wears is a specimen of her "delicate and imaginative skill". Soon her needlework becomes the fashion of her age and people start recognizing her for this extraordinary talent. Her needlework is seen on the "ruff of the Governor; military men wore it on their scarfs, and the minister on his band; it decked the baby's little cap; it was shut up, to be mildewed and moulder away, in the coffins of the dead" (Hawthorne 62). But, she is not allowed to prepare a white bridal dress which indicates the relentless condemnation which society frowned upon her sin. Hester continues to "write her rebellion in lace, outside the boundaries of law" and defends her right to self- reliance in the patriarchal community when it is almost impossible for a lady to do (Hawthorne 262). Relying on her own potential, she works as a seamstress to forge a new life and new identity without conforming to the rules set by the puritans. Nina Baym says "She goes so far in her thinking as to attribute her own law to God, thus denying the entire rationale of the Puritan community, their certainty that their laws conform to divine intention" ( 70)

Hester neither complains against public opinion for her nor claims anything in requital for what she suffers. She starts increasing her activity in the society. She extends her helping hands to the poor by providing them with food and hand skilled plain clothes. When pestilence stalked through the town, she foes round rendering numerous acts of service to those who are afflicted by the disease. "There is a well of human tenderness in her heart which has not been dried up by the indifference, contempt, and cruelty of the people in whose midst she moves about".(Baras 207). Due to her acts of mercy, people are forced to re-evaluate the meaning of the letter 'A' from 'adulterer' to 'able':

Her breast, with its badge of shame, was but the softer pillow for the head that needed one. She was self-ordained a Sister of Mercy, or, we may rather say, the world's heavy hand had so ordained her, when neither the world nor she looked forward to this result. The letter was the symbol of her calling. Such helpfulness was found in her--so much power to do, and power to sympathise - that many people refused to interpret the scarlet A by its original signification.

They said that it meant Able, so strong was Hester Prynne, with a woman's strength.

(Hawthorne 121).

Not only the letter stands for her ability but it has the effect of a cross on Nuns' bosom. She proves that the strength of her character cannot be subverted by the "misguided and thoughtless" portions of the puritan society in which she lives. She gains a respectable position in the society by the dint of her own efforts and compels the people to re-interpret the meaning of the scarlet letter " $A$ " from 'adulterer' to 'able".

Emerson in his essay "Self- reliance" says, "It is easy in the world to live after the world's opinion; it is easy in solitude to live after our own; but the great man is he who in the midst of the crowd keeps with perfect sweetness the independence of solitude" (Emerson 5). She is a self- reliant woman because even by remaining as a member of the puritan society, she separated herself from the conformist life style of her fellow people. Kohhoul Imene also highlights the importance of community to shape once identity 
"This identity is shaped only with the interaction with other selves or other individuals for there is no self apart from the selves of others ... She is seen as an early celebration of democratic individualism asserting itself in a hostile environment formed by a political and religious establishment”. (77-78).

She is self-reliant because despite the scathing remarks and disapproving glares, continues to live her life and raises her daughter. She does not dramatically and apologetically beg for forgiveness; instead, she endures her punishment and ultimately, with her "natural dignity and force of character", she turns a symbol of sin into a symbol of strength.

Though the meaning of the scarlet letter is re-evaluated but she hardly pays any heed to people's reevaluation of the letter. She does not let puritans feel that their punishment has humbled her. Infact "the scarlet letter has not done its office". It does not serve the purpose for which it is meant: humiliate Hester. Even when she is asked to remove the letter she refuses, because for her its removal is as futile as its original placement. When Chillingworth informs her that the badge can be taken off she says, "It lies not in the pleasure of the magistrates to take off the badge, were I worthy to be quit of it, it would fall away of its own nature, or be transformed into something that should speak a different purport" (Hawthorne 127). The animosity towards Hester has softened and eroded but on the other hand she herself has become hard and repulsive. She is indifferent towards that changed attitude of people because she has not given them the power to judge her. Those seven years of her punishment has toughened her to the extent that she is no longer afraid of her husband Chillingworth. She breaks her oath of keeping her husband's identity a secret from Dimmesdale. She feels that her soul is committed to the one whom she loves but not bound by church ceremony, rather than the one whom she does not love but bound by the church ceremony. By hiding the secret of Chillingworth she has surely been untrue to Dimmesdale that she has the power to be true to. Thompson opines that Hester admits to herself that although her redemption exists outside the bonds of strict puritan doctrine, she has an obligation to Dimmesdale. "Her obligation to inform Dimmesdale of Chillingworth true indentity influences her romantic notion of redemption as occurring now" (77). She believes that she has sinned to Dimmesdale by keeping him unaware of the identity of her husband. She blames herself for all the Chillingworth's persecution of her lover Dimmesdale and wants redemption. Her redemption lies to be faithful and devoted to Dimmesdale whom she loves but not to Chillingworth whom she doesn't. Her intense intention to reveal his identity to Dimmesdale leads her to the path of individualism which is the path of $\sin$ in the eyes of puritans. She is humiliated and suffered by her initial act but she does not want to give up her individual right to love Dimmesdale. Her individualism has become a weapon to fire Puritanism.

She cannot see her lover being leeched by her estranged husband, so she decides to commit adultery once more by betraying her husband in order to save the life of her lover. She is willing to risk her own life in order to save the life of the one with whom she feels to be divinely united. "Hester, all by herself, a lonely woman struggling independently for survival in a totally alien land, wins certain excusable sympathy toward her transgressive behavior from the reader". (Wang 547).

Her meeting with Dimmesdale in the forest demonstrates that she is not guilty of her sin but still feels, thinks and acts as an independent woman. She shares her emotions with him ignoring all the constraints imposed on her by the puritan society. She sees her sin as having been no more than the fulfillment of the natural law. Hester whose mind and soul is not bound by the ministerial rules and universal laws urges Dimmesdale to flee from Boston to some other land where they three can lead their life as a family. In the forest, she is invigorated, lets her hair falls down and throws the scarlet letter. But she puts on the letter when she realizes that Pearl is a living embodiment of the letter (a letter endowed with life) and thus throwing the letter away is like throwing Pearl away. For Hester, both Pearl and the letter are not the badges of shame but the badges of love. Her decision to flee away from Boston with Dimmesdale demonstrates her loyalty to both him and herself. "She chooses her own course, dismisses the cultural framework surrounding her, and leans heavily upon creating a personal spirituality exempt from external forces" (Hawthorne 75). In fact her redemption lies in reuniting with Dimmesdale to lead a happy life. Though society changes its perception towards her, but she is not greedy of that respect. She raises herself beyond their life styles. Neither she accepts their forgiveness, nor does she want to forgive them. Her morality arises to an extent that she never raises her head to receive their greetings, instead lays her finger on the scarlet letter and passes away on. 
Hester does not conform to the puritan's ideology but is guided by her own beliefs and instincts in taking her judgments. She posseses the fortitude and mental balance which is stronger than the wornout principles of the puritans. Though she has the vigor, but she is not rebellious and disobedient to the traditions of the community she belongs to. She does not separate herself from the society's conventions but distinguishes herself from the women who are part of that society. She refuses to be defined by society and its trivial constraints, continues believing in her potential despite her crime, and comes to define herself as she sees fit; thus relying on her individual perception and openly disregarding the collective consciousness. Hester's unshakable trust in herself, her unconditional love for Dimmesdale, and her profound devotion to her daughter, empowers her to resist and transcend enforced Puritan conformity. She celebrates her individuality and wins over society's restrictions.

\section{REFERENCES}

Baym, Nina. "Hester as Hero". Women's Issues in Nathaniel Hawthorne's The Scarlet Letter:n.d.6773. Print.

Hawthorne's The Scarlet Letter. Ed. Gary Scharnhorst. New York: Greenwood Press, 1992. 17693.Print.

Barus, Jumat. "Nathanial Hawthorne's The Scarlet Letter as a Tragic Love Story". JULISA 10.2 (2010):202-205. Print.

Bercovitch, Sacvan. The Office of The Scarlet Letter. Baltimore: The Johns Hopkins University Press, 1991.Print.

Eeckman, Sylvia. "Women inThe Scarlet Letter. Ghent University (2008): 1-68.Print.

Emerson, Ralph Waldo. "Self-Reliance." Vol. 2 of The Complete Works of Ralph Waldo Emerson, Centenary Edition. Boston: Houghton, Mifflin and Company, 1903. 44-90 .Print.

Emerson, Ralph Waldo. "Self-Reliance”. n.p. (1841):1-21. Web. 10 August 2014.

Gray, Richard. A History of American Literature. New York: Wiley-Blackwell, 2004.Print.

Hawthorne, Nathaniel. The Scarlet Letter. Hertfordshire: Wordsworth Classics, 1999.Print.

Imene, Kahhoul. Puritanical Dimensions in The Scarlet Letter: Moral Demends Versus Individual Needs. Diss. Mohamed Khider U, 2011/2012. Print.

Last, Suzan. "Hawthorne's Feminine Voices: Reading" The Scarlet Letter" as a Woman." The Journal of Narrative Technique (1997): 349-376.Print.

Leland S. Person, Jr. "Hester's Revenge: The Power of Silence in The Scarlet Letter".

Nineteenth-Century Literature 43. 4. ( 1989): 465-483. Print.

Maniere, William R. "The Role of Sympathy in The Scarlet Letter." Texas Studies in Literature and Language 13 (1971): 497-507.Print.

Mansilla, Matilda. "An Insight into the Inward Sphere in Hawthorne's Scarlet Letter" Many Sundry Wits Gathered Together. (1916): 215-225. Print.

Martin, Terrrence. 1965. Nathaniel Hawthorne. New York: Twaynes Publisher Inc. Print.

Person, Leland S. The Cambridge Introduction to Nathaniel Hawthorne. New York: Cambridge University Press, 2007.Print.

Ruland, Richard, and Malcolm Bradbury. From Puritanism to Postmodernism: A History of American Literature. New York: Viking Adult, 1991 Print.

Rutherford, B Markella. "A Bibliographic Essay on Individualism”. n.p. (n.d.): 116- . Web. 13 November 2014

Thomson, Lehtie Chalise. "A Moral Wilderness": Nathanial Hawthorne's The Scarlet Letter. Diss. Boise State U, 2011.Print.

Wang, Quan. "A Warrior or Not? A Comparative Study of The Scarlet Letter and "No Name Woman". Rupkatha Journal on Interdisciplinary Studies in Humanities 3.4 (2011): 546-554. Print.

Wright, Sarah Bird. Critical Companion to Nathaniel Hawthorne: A Literary Reference to His Life and Work. New York: Infobase Publishing, 2007.Print. 


\section{AUTHORS' BIOGRAPHY}

Ms. Mursalin Jahan, is an Assistant Professor at Integral University, Lucknow, India. She is also a research scholar pursuing her $\mathrm{PhD}$ in English Literature. She has a vast teaching experience of twelve years in which she dealt primary, junior, senior, senior secondary, graduate and post graduate students, teaching English Language, English Literature, Professional Communication and Soft Skills as the main subjects. Her area of specialization is American Literature. She presented many papers in national and international conferences and seminars.

Prof. Syed Zaheer Hasan Abidi, is a Senior Professor and Head in the Department of English/Languages \& Dean, in Faculty of Humanities \& Social Sciences, Integral University, Lucknow. He was educated at the Universities of Gorakhpur and Allahabad. He held the position of Professor \& Head of the Department of English \& Modern European Languages, University of Lucknow, Lucknow. During his teaching career of almost 45 years, 35 research scholars were awarded the Ph.D. degree under his supervision. He contributed numerous research articles to different journals and delivered keynote addresses in various national and international conferences. $\mathrm{He}$ is the founder and editor of the journal SPIEL (Society for the Promotion of Indian English Languages). 